\title{
Description of a New Acanthiza from Western Australia.
}

\author{
By Alex. Wm. Milligan
}

(Honorary Ornithologist, Perth Museum, Western Australia).

A NEW Acanthiza was secured by Mr. Fred. Lawson at Wurarga, Yalgoo Goldfields, Murchison, on the ist September last. Wurarga is about IOO miles inland from the Western coast, well beyond the confines of the characteristic rain-belt, and in about the same latitude as the boundary line between Queensland and New South Wales.

The new species is closely allied to Acanthiza chrysorrhoa (Gould), and bears, in my opinion, affinity in the same degree to that species as $A$. tenuirostris (Zietz) does to A. reguloides (Vig. and Hors.) It is, in fact, a pallid and miniature form of $A$. chrysorrhoa. I do not declare it to be the Western form of the latter species, as our coastal form in temperate districts much resembles the Eastern one, but rather regard it as the northern and interior one. The points of distinction between the two species are many, but the principal ones are these :-The new bird is much smaller; its under surface is almost uniform white ; and its whole upper surface generally is lighter in colour. In particular, the forehead band is better defined, and conspicuously white; the crown of the head is not so dark; the white spots of the head are fewer; the sides of the head and cheeks are white; an obscure nuchal band of light greyish-brown and a mantle of dingy olive-grey take the place of the rich olive-yellowish of the upper surface of the coastal and Eastern species ; the rump is not yellow, but the same colour as the mantle, and the upper tail coverts are lighter yellow; the basal halves of the tail feathers are white and not yellow, and the terminal halves of some only of them are tipped with white, and that very narrowly; and the irides are dull brown, and not greyish-white or light yellow. Three adult birds have been secured, two males and one female, the latter and one of the males being a breeding pair. Mr. Lawson says the birds are far from common.

The specific description is as follows:-

Male.-The frontal band, lores, throat, cheeks, chest, abdomen, sides of body, under wing coverts, and under tail coverts white, except a very faint cream-coloured tinge on chest and sides of body ; a dusky spot in front of eye ; ear coverts pale grey, with whitish margins ; feathers of crown blackish-brown, a few of the feathers having white-spotted tips, the remainder with pale grey margins ; feathers of the hinder crown brown, with pale grey margins; an indistinct nuchal band of greyish-brown extends from ear covert to ear covert ; mantle and rump dingy greyisholive; wings dark brown, the secondaries with paler brown margins; upper tail coverts light chrome-yellow, with white bases to tail feathers; latter blackish-brown, with only two or three of the undermost feathers tipped white, and those very 
narrowly; under surface of tail feathers ash-coloured, with distinct transverse bars of a deeper colour; beak, legs, and feet black; irides dull brown. Flesh measurements-length, 3.6 ; wing, 2.3 ; tail, I.8 ; tarsus, .7 ; culmen, .45 inches.

There is little difference between the sexes in appearance, except, perhaps, that the female has a shorter bill and narrow greyish-white edgings to one or two of the tail feathers.

Types.-In the Western Australian Museum, Perth.

Fi I beg to distinguish the new species by the scientific name of Acanthiza pallida, and by the vernacular one of "Pallid Tit."

\section{Stray Feathers.}

Swallows on 'CHANGE.-Last week a pair of Swallows (Hirundo neoxena) suddenly appeared in the city and took up their abode under the verandah of the Launceston Stock Exchange. Every summer a pair nests under this verandah. Woe betide anyone who attempts to molest the birds on their nest; the members of the 'Change are very jealous of their little feathered friends.Frank M. LitTler. Launceston, 23/6/03.

[Re this bird an interesting note is given by Mr. T. Carter, in his "North-West Notes" in this issue.-EDS.]

Homestead Notes (North Queensland).-We have eight or nine different Finches here now, two or three breeding-gouldia, cincta, and castanotis. Saw a nice mob of about three dozen of Munia pectoralis a few days ago. First week in May I saw a nest of Moreton Bay Rosellas (pallidiceps) taken out of gum tree by a timber getter-three young birds well feathered and two only just hatched. Only one small spout in the limb of tree, so there was certainly only one nest. Was very much puzzled at time. This must have been a similar case to one mentioned by you in Emu. I think the drought must be the cause of so many birds nesting out of their usual time.-John H. SmedLey.

WOOD-SWALlows as HONEY-EATERS. - Re remarks in last issue of The Emu (page 68), I have kept two pairs of Wood-Swallows for the last seven months. They were turned out into an aviary in which there was honey for some Meliphagida. No sooner were the Wood-Swallows at liberty than they made their way to the pot, and seemed to recognize it as a natural diet. At present they live principally on fruit and honey, with a little lark food and occasional insects by way of a treat. They visit scented flowers, but I do not know whether in search of honey or not. The brush tongue would seem to indicate that honey was in the wild state a food sometimes used, though perhaps, as in the case of some honey-eating Parrots, not necessary always to subsistence--(MISS) HeLEN BowIE. Clifton Hill, near Melbourne. 


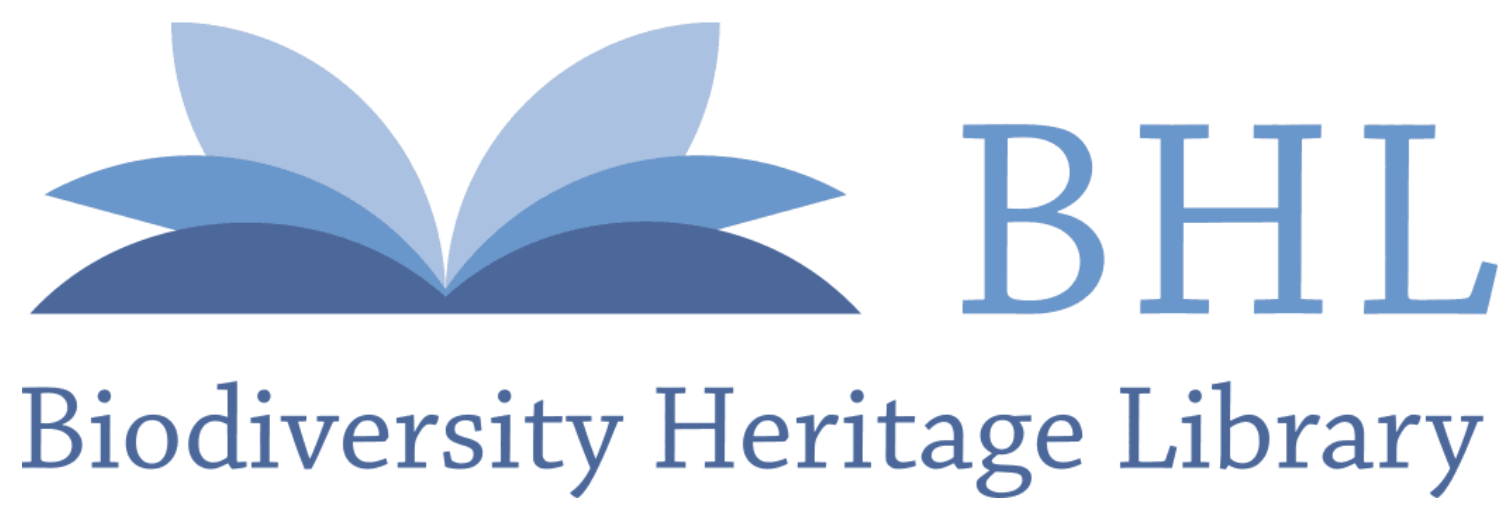

Milligan, A W . 1903. "Description of a new Acanthiza from Western Australia." The Emu : official organ of the Australasian Ornithologists' Union 3, 111-112. https://doi.org/10.1071/mu903111.

View This Item Online: $\underline{\text { https://www.biodiversitylibrary.org/item/36066 }}$

DOI: https://doi.org/10.1071/mu903111

Permalink: https://www.biodiversitylibrary.org/partpdf/172040

\section{Holding Institution}

American Museum of Natural History Library

\section{Sponsored by}

Sloan Foundation

\section{Copyright \& Reuse}

Copyright Status: NOT_IN_COPYRIGHT

This document was created from content at the Biodiversity Heritage Library, the world's largest open access digital library for biodiversity literature and archives. Visit BHL at https://www.biodiversitylibrary.org. 